\title{
THE STUDY OFMOTIVATION TO BE SCIENCE TEACHER
}

Yuli Rahmawati, M.Sc, Ph.D

Department of Chemistry, Faculty of Mathematics and Sciences, Universitas Negeri Jakarta, Jl. Pemuda No 10.Rawamangun. Jakarta. Indonesia

\begin{abstract}
This study aims is to examine several factors that influence people to choose the profession as a science teacher. The motivation is important factor that influence individual to have a good performance in their activities. Descriptive qualitative methodology through the semi-structured interview method is chosen to get the meaningful information of this study. The data was collected from four experienced science teachers who come from different countries which are Australia, America, Africa, and Philippines. The study found that several factors that motivated participants to be a teacher are family member, aspiration, role models, previous teaching experiences, teaching as powerful and manageable job, and educational background. However, all participants found interactions with their students have motivated them to be good and professional science teachers.
\end{abstract}

Keywords

Motivation, science teacher, descriptive study

\begin{abstract}
Abstrak
Studi ini bertujuan untuk mengetahui beberapa faktor yang mempengaruhi seseorang untuk memilih profesi sebagai guru sains. Motivasi merupakan factor penting yang mempengaruhi seseorang memiliki kinerja yang baik dalam pekerjaannya. Metodologi deskriptif kualitatif melalui metode interview digunakan untuk mendapatkan informasi yang bermakna. Data diperoleh dari 4 orang guru sains yang berpengalaman dari Australia, Amerika, Afrika, dan Philipina. Hasil studi menunjukkan beberapa faktor yang mempengaruhi motivasi menjadi guru yaitu: keluarga, cita-cita, role model, pengalaman mengajar sebelumnya, nilai mengajar sebagai pekerjaan yang memiliki pengaruh yang besar serta pekerja yang dapat diatur dengan baik, dan latar belakang pendidikan. Semua subyek studi sepakat bahwa interaksi dengan murid-murid mereka telah memotivasi menjadi guru sains yang baik dan profesional.
\end{abstract}

\section{Kata kunci}

Motivasi, guru sains, studi deskriptif

\section{Introduction}

There is no doubt that teacher profession plays important role to shape the young generation through education process. According to Richardson and Watt (2006, p.27), "quality of teachers and teaching are central to the development and maintenance of an intelligent and informed citizenry." Therefore, this profession involves high responsibilities which are not only transferring the knowledge to the students, but also supervising, caring, understanding, and emancipating. People have different factors that motivate them to choose the profession as a teacher. However, their motivation is important to guide them as a good teacher. Therefore, this study addressed the issue of motivation to be a teacher which influences the effectiveness and improvement of education process.

The data was collected from four experienced science teachers who come from different countries which are Australia, America, Africa, and Philippines. The interview investigates their motivation to be a science eacher. The study found that there were several factors that influence them to choose the profession as a teacher which are family members, role models, previous teaching experiences, and educational background. In this study, the research findings on their motivations and also other findings which explore their teaching career. 


\section{Literature Review}

Becoming a teacher is a great work, it is not only transferring the knowledge and performing in classroom, but also educating, supervising, caring, and understanding. Furthermore, according to Henniger (2004), teaching also can be perceived as an art which involves the creative interchange between teacher and students to create the inspired education process. One of powerful aspect to be a great teacher is motivation. Motivation could lead teacher to give the best performances and shape their students as a holistic learner. Unfortunately, not all teachers are motivated to be teachers because several reasons such as the welfare and less appreciated from the society. However, the journey as learners and teachers changes their mind. For example, some of them become motivated because of their teacher as a role model and the others are motivated because of interaction with their students. Therefore, I believe that becoming a teacher is a calling from the hearts which encourage them to be good teachers.

Berelson and Steiner (1964) \& Tracy (2000) as cited in Ofoegbu (2004, p.2) defined motivation as "all those inner striving conditions, described as wishes, desires, and urges to stimulate the interest of a person in an activity". Furthermore, according to Moore (1995, p.209), "motivation can be defined as forces or drivers that energizes and direct us to act as we do". Therefore, motivation could empower individual to perform the best in their activities. As a teacher, teachers who have good motivation will try to give the best in education process which influence the students' learning.

Teachers' motivation is important because it effects the students' motivation (Jesus \& Lens, 2005). Furthermore, teachers have both intrinsic and extrinsic motivation which influences them to do their responsibility (Moore, 1995; Richardson \& Watt, 2006).
Teacher who are intrinsically motivated will be view their job as a process which need to be improved every time, for example they will try to find the ways to create the meaningful and interesting learning experiences for the students. This motivation will influence the teacher to be creative in teaching strategies, evaluation, and interaction with the students. Furthermore, extrinsic motivation is also influenced teachers to perform better, such as salary. Even though, in my opinion, intrinsic motivation more influence than the extrinsic one. But, teachers are also human who need to fulfill their needs. Therefore, both intrinsic and extrinsic motivations need to be concerned to improve the quality of teachers which will influence the education process.

\section{Research Method}

The study employed descriptive qualitative methodology to explore motivation of the four science teachers. According to Gay and Airasian (2000, p.8), "a descriptive study determines and describes the way things are". Descriptive qualitative mainly employs observations and interview as data collection methods. In this study, data was obtained from the semi-structured interview which is guided by several questions to investigation the factors which influence the participants to be a teacher. The participants are four experienced science teachers from different country: Australia, America, Africa, and Philippines who have the minimum teaching experiences for 9 years. The participants are:

a. Rebecca, she has teaching experience in Primary and High School level in Physics, Chemistry, and Human Biology. She had aspiration as a teacher. Then her interaction with the children more motivated her. She compared teacher's job with other jobs which less interesting than to be a teacher. She is one of enthusiasm teachers, who always applies varied 
strategies to engage with her students. She focuses to develop her career, especially as decision maker.

"Teaching is not to be regarded as a static accomplishment like riding a bicycle or keeping a ledger; it is, like all arts of high ambition, a strategy in the ace of an impossible task"

Larence Stenhouse (DfEE, 1999:95)

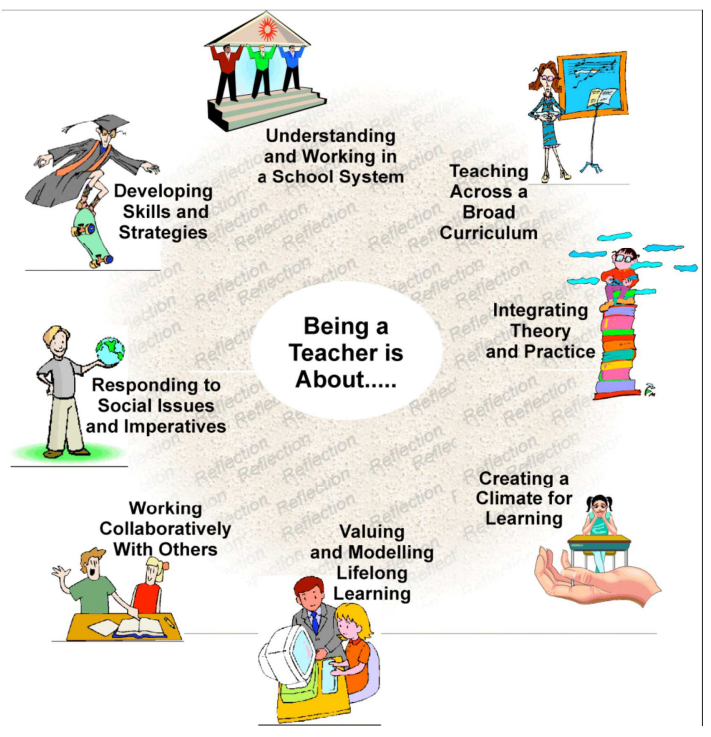

b. Andrew, he has teaching experience in High School and University level in Physics. He has not have aspiration as a teacher. Even through, until the government chose him to be a teacher, he still unmotivated, but in the third year becoming a teacher, he found that interaction between students is very interesting. Then, he tried to engage with his students, even though, sometimes it failed. Now, he teach students science teacher.

c. Michelle, she has teaching experience in Middle School level in Mathematics and Science Integrated. She had not have aspiration as a teacher. Even though, one of her family member is a teacher. But, when she taught her niece who was student, she found that teaching is very interested. Therefore, she chose to be a teacher. She also admires three of her teachers in high school. She is very enthusiasm teacher. She used to applied constructivist approach through sciencebased inquiry curriculum. She always tries to engage with her students. Therefore, sometimes, she forgot to manage the time. She has many plans to develop her career as an educator.

d. Sarah, she has teaching experience in High School and University level in Science Integrated. She has not have aspiration as a teacher. Even though her mother was a teacher, but she found her teacher is very good teacher. Therefore, her chemistry teacher is the one who motivates her to be a teacher. She used to try to teach science in meaningful learning experiences such relate science with students' life. At the first time, she was very strict and discipline teacher, but the evaluation from the students motivated her to more understanding. She has many plans as decision maker and as teacher of science educators.

The interview is a process to investigate detail information on people respond and events (Burns, 1996). It involves some form of interaction between researcher and the participant. In general, interviews can give useful and detail information if the researchers cannot conduct field observations. Compared to observation, the interviews can control the information that you need through the specific questions (Creswell, 2005). In this study, interviews employ intensive steps of coding to find the themes, issues, topics, concepts. Then, content analysis to find the meaning of interviews text (Burns, 1996). 


\section{Findings}

The data was collected through the semistructured interview. Several questions guide the researcher to investigate the motivation of the participants. But, the questions are extended depends on the response of the participants. The questions are not only about motivation, but also their background and how their teaching experiences which are influenced by their motivation to be teachers. There are many reasons for being a teacher. The respondents in this research also show some factors that influence them to be a teacher. Some of the reasons will be explored in the findings.

\section{a. Family Members}

Having family members who become teachers doesn't influence much on the participants to be a teacher. Three of the four participants have family member who became teachers. However, they didn't find themselves are influenced by their family member who are teachers. Moreover, their parents were disappointed with them because of choosing to be a teacher. Their parents would like them to have profession as a doctor, lawyer, and engineer.

"I had family members are professor in university, but no one who became teachers. That's why my parents were very disappointed. Because they are hoping that I become a doctor".

"My mom was a teacher. She just taught for 10 years and then retired to become a housewife. But, she isn't the one who motivated me to be a teacher"

"My mom taught typing and shorthand in business school, my auntie teach in the high school and became principle, my cousin is music teacher and became principle, my great grandmother was also a teacher, but I didn't know much. My auntie teaches piano to students. So, some of them are teachers in the family. But, my motivation become a teacher isn't much influenced by them".

Even though, having family member could influence people to be a teacher, but it does not happen in this study. All of them chose their teachers as those who most motivated them as a teacher.

\section{b. Aspiration}

Aspiration is important part of individual life which could guide them to achieve the goal in their life. But, aspiration could change through the journey of people's life. This also happened with the people who choose to be a teacher. According to Banks (1989) as cited in Miller \& Endo (2005), most students choose the job as a doctors, and lawyers. It because, the community tends to appreciate these kinds of jobs which are highly paid. Furthermore, the parents also tend to encourage their children not to become the teachers. This study found that only one from the four participants who had aspiration to be a teacher since she was a child. It also happened because of the parent gave her the freedom to choose the one that she like. However, three of them didn't have aspiration as a teacher. But, it changed through their journey, which disappointed their parents wish.

"I have a few different aspirations, one was a teacher, one was a librarian, and the nurse. My mom told me the story when I was a child, I had a doll and I didn't want to play with the doll, my grandfather gave me the medical care kits. Then, I had some books at home, and all of the children who lived in my street, if they wanted to borrow the books, they had to fill the form. For the teacher, gave the children spelling test. 
My mom and dad were more like into history and literature than science. So, they were surprised that I quite like enjoyed science and math. I did do literature and history at school, but I like science more. In year 12, in my chemistry class, I would explained to my classmate and I remember my teacher at year 12, saying to me you would be a good teacher and I think that's when I actually thought about doing that at university, beginning at year 12 ".

"... when I was a child I would like to be an engineer. Then, it changed after my third year of teacher, because of interaction with the students"

"... I want to be an architect, and then I want to be a research scientist. I don't want to be a teacher until my second year of college, I changed my major. Because my aunt in Romania sent her oldest daughter to live with my husband and I. She was in fifth grade, 10 years old and I was so exciting, working with the kids at that age. That was really fun, so I would like to be a teacher. She is the one who motivated me to be a teacher. Because I involves in her learning, going to school, talk to the teachers, and visited the classroom"

"Before, I had desire to become a teacher, I want to become a sister. But then, I moved on to the high school, I had a good chemistry teacher. So, I just wanted to become like her. She had this very caring attitude toward all of us. So, we were not spied of the difficult nature of the subject. We did not really fell so hard of the questions, She would not perceive to the new topic, until we understood the topic. I

know it is not the highly paid job, but I just wanted to become the one"

Peoples' aspiration when they were child could be changed through their lived experiences. Their family could influence the aspirations when they were a child. Based on the interview data above, it is clear that their journey as a learner and a teacher much influenced them than their child's aspiration.

\section{c. Role Models}

Teachers as role models play important role to influence an individual become a teacher. Two of the participants can identify that their teachers influenced them to choose the profession as a teacher. Their previous teachers not only influenced them in choosing job as teachers but also influenced their style of teaching.

"I have three teachers, my Math teacher at the high school, I think he was not just a math teacher, but he was Math. He was logical, the way he developed the idea of teaching, you see things, and you could have deep understanding. So, he didn't just presenting the math, but he helped us to understand, he is a model of mathematical thinking, so I really liked that. Another one, he was my English literature teacher in the high school, and he always shown us to examine the ideas that we hold within different perspectives. Anything can be changed. He also made me looked teacher as people. And the third one is the coordinator in my school who always encouraging in always challenge us to do our best. If I am interested in anything, he will find the way to support it. That's three amazing people, I would like to be like that" 
"Before, I had desire to become a teacher, I want to become a sister. But then, I moved on to the high school, I had a good chemistry teacher. So, I just wanted to become like her. She had this very caring attitude toward all of us. So, we were not spied of the difficult nature of the subject. We did not really fell so hard of the questions, she would not perceive to the new topic, until we understood the topic. I know it is not the highly paid job, but I just wanted to become the one"

Unfortunately not all teachers are effective to become role models. One participant identified that he had good and bad experiences with his teachers. He said : "No one in my family is a teacher. But I have a good teacher who motivated me to be a teacher, but I also had a chemistry teacher who taught in the bad way, I didn't understand then I failed chemistry. So, teacher not influenced much in my motivation to be a teacher". According to Hare (1993, p.117), "the good teachers believes in his subject and is genuinely, unashamedly enthusiastic about it. Moreover, the love of teaching can be identified in two components which are passion for the subject matter being taught and delight found in teaching others (Henniger, 2004, p.12). Therefore, teachers who show their love for teach the students, enthusiastic with the subjects, and caring their students are those who will be role models for their students. Therefore, it is important for the teacher to be aware of their role on their students' life.

\section{d. Previous Teaching Experiences}

All the participants are experienced teachers. The minimum experience that participant had is 9 years. All of them had previous positive experiences in teaching. Therefore, their previous experiences motivated them to be teachers. One participant had positive experience while doing practical teaching at high school. She noted,

"... I went to university, and the first two years, it was fine. But when I went to my third year of university, I went to a school to do like practical for ten weeks, I loved that. The teaches were very supported at that school, my university lecturers were very supported, at that year at university, very nice lecturers, very encouraging all of students to have experiences in the school, and I just going there and enjoying practical experiences, very enthusiastic..."

The other two participants are motivated to be a teacher when they interact with students. One participant stated,

“...Then, after six years in that school, I was hired to magnet school where students came from others districts, they came there because they really interested in Science and Math. I started the programmed and develop the curriculum. So, I did that for 7 years, I was really exciting worked with highly achieving and highly motivated students".

Another participant commented,

"The good teacher, I consider her as a starting point. But, the actual dealing with the students grows my motivation to be a teacher. It was full feeling to see them learn something, to help them to understand more about physical world, it also makes me happy to see them learn something that they can use, like when I teach concept on 
hygiene, why they should cook their food. They become conscious, that kind of looking of student discovery how useful the science in the day activities, that is my reward."

The teaching experiences provide the participants insight to be a teacher. Interactions with students, helping other people, and impression from students or parents give them intrinsic motivation to choose the job as teachers.

\section{e. Teaching as Powerful and Manageable Job}

The interesting findings of the interview are teaching as powerful and manageable job. One participant commented,

"...become a teacher give you power, and second I call this profession is liberal profession and you have authority to do something inside the classroom. What I mean is we can make decision. It is also easy to manage the time which we still have the time for ourselves, not like at office in the morning until afternoon within the strict time. But, looking on salary, salary could not be a motivation to be a teacher"

The other participant stated,

“...it's a good profession especially, if you are going to have children. You could manage some holidays."

Even though, becoming a teacher is high responsibility but the participants mentioned that it is easy to manage time and work compare to other jobs. According to Henniger (2004) the time flexibility and management influence an individual to choose the job as a teacher. Furthermore, the power of teacher to manage the classroom motivated the participant to stay being a teacher. Even though, there is low salary for teacher, but positive thinking on the advantages of being a teacher could influence individual to choose this job.

\section{e. Educational Background}

Compared to other factors such as teaching experiences and role models, educational background not much influenced the participants to be teachers. Two participants decided to choose college of education because of they admired their teachers. But two of these participants recognized that interaction with students when they teach is the major factor which influences them to be a teacher. The first participant stated,

"... I was at university and we had practical experience at university, in two weeks and another two weeks and again and again, and then 10 weeks in a school, working in the school before you finish your degree, and I really enjoyed it"

Another participant commented, "

\section{I started teaching in 1998. I graduated in March 1998, so straight away. I started teaching in secondary school, which was gathering to special students which means they were really smart kids, they were promoted to their level and also special in the way, they were kick out from the normal school. I taught both of the types of students, I found it's very challenging."}

The other two participants had specific case. The first one made decision to become a teacher after enter the university. She said, "I have bachelor degree in humanities. When I started I was in science major, and then, so I do have a lot of math and science courses that I took in the undergraduate. But, then I switched the majors because I taught I want to be a teacher in the elementary school". The 
other participants became a teacher because of the government asked him to be a teacher. Even though, he didn't want to be a teacher, his teaching experiences encourage him to be a teacher. Therefore, afterward, he took the further education in science education.

\section{f. Other Findings}

The factors that influenced the participants to be a teacher have effects on their teaching style. They became enthusiasm and motivated teachers. They had philosophy of teaching which guide them to be good teachers. These are the teaching philosophy of four participants,

"... All children can learn, children learn in different ways. So that, you should put the opportunity for those children to learn. Probably several things at the one time. Because you always got 30 children in your classroom. So, you have to give them opportunity to do different things and learn things different ways, and to get children to talks about what they found with their experiences. And keeping children in behaviour management which is the issue in Australian school. Providing the structured for the children that my understanding, my language, they know what I expect of them, they know what to do to provide a collaboration, happy working environment'

"... allow my students to be what they want to be. So, I always concern how to motivate them. They should understand what they want."

"I have few ideas that guide the way I am teaching. Every student can learn and successful. The second is learning should be interesting and enjoyable, and rigorous. Third, I believe that students don't learn by sitting there and listen to me, I think they learn by interacting with me and materials, the constructive knowledge, build the knowledge".

"My philosophy of teaching combines pragmatism, esthetic realism, and critical philosophy. Pragmatism is about making knowledge practical and useful. The esthetic realism is balance, because the real physical world always compose the opposite, which actually complement each others. You bring your students to like different thing and see how they work together. Critical philosophy which always examining different things. It is still developing until now. I also remember constructivism where you acknowledge each learner. They construct the knowledge three because they have different experiences."

The teaching philosophy influenced the participants to create the meaningful learning experiences for their students. They apply varied teaching strategies in the classroom such as constructivist approaches through inquiry, practical work, and demonstration. One participant stated, "I do a lot of discovery things, developing concepts, and inquiry, a lot of group work. I applied more constructivism approaches". Furthermore, the problems or difficulties that they found in teaching did not discourage them to be a teacher. For example, one participant commented,

"I thinks the problems don't discourage me, because I get such a good feeling when I say the kids learn, someone says thanks you or give the flower or chocolate, I just feel so touch that I help someone, or the parents ring up or anything, I think that is charging which 
helping the children and guide them. I want to be a motivator".

The other participant perceives the problems on the positive views. She found the problems encourage her to find the ways for helping the students. Moreover, one participant from Philippines mentioned the problems that happen in most Asian countries. She stated, "What is really discourage is the work condition such as the class size, the require number of time you suppose to assess, finish the subject. So, you are overwhelmed with the paperwork. However, she always tries to find the ways to overcome these problems. Furthermore, four of participants have their future plan as a teacher such as develop their professional career as a teacher and a decision maker. For example, one participant stated, "I want to become the education administrator, but I also want to maintain in the classroom, I am especially targeting pre service science educator. When you train the teacher, because they will teach the students. I would like to become the education administrator, I would have opportunity to involve in decision making, unless you don't have position, you will not have voices." Based on the findings, it is clear that the factors that motivated the participants to be a teacher influence them to be good teachers.

\section{Conclusion}

Based on the above discussion, several factors that motivated participants to be a teacher are family member, aspiration, role models, previous teaching experiences, teaching as powerful and manageable job, and educational background. However, all participants mentioned that the major factor that influenced them to be a teacher is previous teaching experiences when they interact with students and help the students. In short, intrinsic motivations encourage them to neglect the external factors such as low salary. The other factor that more influenced them is the role models, they found their teachers motivated them to be a teacher, not only to choose the job as a teacher, but also their teaching styles. However, compared to these two factors, the other factors such as family member, aspiration, teaching as powerful and manageable job, and educational background less influenced them. Therefore, it is important for teachers to have motivation being a teacher which influenced them to be enthusiasm teachers.

\section{Acknowledgement}

The author would like thank Dr. Rekha Koul from SMEC, Curtin University for being a great facilitator for conducting this study. The author also would like to thank four science teachers who being helpful and enthusiasm participants. Finally, thanks to all the people who I have not mentioned here, thank you for the guidance and encouragement.

\section{References}

[1] Anderson, G.,\& Arsenault, N. (1998). Fundamental of educational research. London and New York: Taylor \& Prancis Group.

[2] Burns, Robert B. (1996). Introduction to research methods. Australia: Longman.

[3] Cohen, L., Manion, L., \& Morrison, K.(2000). Research methods in education. London and New York: Taylor \& Prancis Group. 
[4] Creswell, J. (2005). Educational research: Planning, conducting, and evaluating quantitative and qualitative research. New Jersey: Pearson Prentice Hall.

[5] Gay, A.L., \& Airasian, P. (2000). Educational research: Competencies for analysis and application. New Jersey: Pearson Prentice Hall.

[6] [Graham, A. \& Phelps, R. (2003). Being a teacher': developing teacher identity and enhancing practice through metacognitive and reflective learning processes. Australian Journal of Teacher Education, 27(2),1-14.

[7] Hare, W. (1993). What makes a good teacher. Canada: The Althouse Press.

[8] Henniger,M.L. (2004). The teaching experience:An introduction to reflective practice. New Jersey: Pearson Prentice Hall.

[9] Jesus, N.D.d, \& Lens, W. (2005). An Integrated model to the study of teacher motivation. Applied Psychology: An International Review, 54(1), 119-134.

[10] LeCompte, D.M. \& Preissle, J. (1993). Ethnography and qualitative design in educational research. New York: Academic Press, Inc.

[11] Miller, P.C. \& Endo, H. (2005). Journey to Becoming a Teacher: The Experiences of Students of Color. Multicultural Education, 13, (1), 2-10.

[12] Moore, K.D. (1995). Classroom teaching skills. New York: McGraw-Hill, Inc.

[13] Ofoegbu., F.I. (2004). Teacher motivation: a factor for classroom effectiveness and school improvement in Nigeria. College Student Journal. Retrieved from http://findarticles.com/p/articles/mi_m0FCR/is_1_38/ai_n6073200.

[14] Richardson, P.W. \& Watt, H.M.G. (2006).Who chooses teaching and why? Profiling characteristics and motivations across three Australian universities.Asia-Pasific Journal of Teacher Education.34(1), 27-56.

[15] Sells, S.P., Smith, T.E., \& Newfield, N. (1997). Teaching ethnography research methods in social work: A model course. Journal Social Work Education, 33(1), 167-184.

[16] Wiersma, W. (1991). Research Methods in Education. London: Allyn and Bacon.

[17] Scdmier, L. (2007).If you want to be a teacher. Retrieved from The NC Education Place, http://www.geocities.com/ educationplace/being.html, on $2^{\text {nd }}$ October 2007. 